Article

\title{
Competitive Priorities, Employee Management and Development and Sustainable Manufacturing Performance in Asian Organizations
}

\author{
Dotun Adebanjo $^{1}\left(\mathbb{D}\right.$, Pei-Lee Teh ${ }^{2, *}$ C , Pervaiz K Ahmed ${ }^{2}$, Erhan Atay ${ }^{2}$ and Peter Ractham ${ }^{3}$ \\ 1 Business School, University of Greenwich, London SE10 9LS, UK; D.Adebanjo@greenwich.ac.uk \\ 2 School of Business, Monash University Malaysia, Selangor Darul Ehsan 47500, Malaysia; \\ pervaiz.ahmed@monash.edu (P.K.A.); erhan.atay@monash.edu (E.A.) \\ 3 Thammasat Business School, Thammasat University, Bangkok 10200, Thailand; peter@tbs.tu.ac.th \\ * Correspondence: teh.pei.lee@monash.edu; Tel.: +60-3-55144971
}

Received: 10 June 2020; Accepted: 29 June 2020; Published: 1 July 2020

\begin{abstract}
This study investigates the relationships between three dimensions of competitive priorities (customer focus, product innovation and delivery) and how Asian manufacturers manage and develop their employees and the consequent effect on sustainable manufacturing performance. Three dimensions of manufacturing performance are considered in this study-quality performance, production flexibility and operations cost. This study uses 259 datasets collected from manufacturers in four Asian countries. Structural equation modeling and mediation analysis are performed to test the relationships. Results show that there is a significant positive and mediating relationship between the competitive priority of product innovation, employee management and development, quality performance, production flexibility and operation cost. However, such significant relationships do not exist with competitive priorities of customer focus and delivery. Organizations are constantly faced with the problem of determining which competitive priorities to focus on. However, different competitive priorities have different effects on how the employees are managed and developed, and ultimately, on organizational performance and competitiveness. There is a need to focus on innovation-led strategies that relate to sustainable outcomes. This is one of the first studies in Asia to understand the multilateral relationships between different competitive priorities and different performance dimensions when employee management and development intermediate.
\end{abstract}

Keywords: competitive priorities; employee management and development; manufacturing performance; survey

\section{Introduction}

Manufacturing firms have been regarded as being a key contributor to negative environmental impacts and consequently, the need to become more sustainable in operations has become an imperative [1-5]. According to Zailani et al. [6], organizations need to enhance their strategy to remain competitive while also developing sustainability in their supply chains. The need to remain competitive leads to a need to examine the competitive priorities of manufacturing organizations. Competitive priorities are a key element of operations strategy that have generated significant interest in academic literature. Many studies have suggested that the choices that manufacturing organizations make, with respect to the competitive priorities, are important determinants of their overall manufacturing strategy [7-10]. Hence, the competitive priorities chosen by a manufacturer will influence the operational activities deployed by that organization. Several studies, including Berry et al. [11] and Prester [12], have sought to identify and categorize competitive priorities and 
commonly cited ones including cost, quality, delivery, flexibility, innovation and dependability [13]. This study investigates the relationship between different competitive priorities and the way in which Asian manufacturers manage and develop their employees and the consequent effect on manufacturing performance. In effect, the study evaluates how strategy can influence management practice to affect organizational success. The study is based on data collected from manufacturers in four Asian countries with well established manufacturing sectors-China, India, Malaysia and Taiwan.

The importance and need for research into the links between competitive priorities and employee management practices have long been recognized [14], and this study contributes to the ongoing debate. The motivations for this study are three-fold. Firstly, studies such as those by Cai and Yang [13] and Prester [12] have examined the relationships between competitive priorities and other organizational dimensions such as the business environment. Cai and Yang [13] found that organizations may choose to trade-off competitive priorities such as cost and quality, and these trade-offs can affect organizational outcomes. Prester [12] elaborated further and stressed that organizations try to achieve their competitive priorities by deploying the right operating practices. The study further identified such practices to include facilities, technology, capacity and human resources. In this study, we focus on the human capital dimension and in particular, how human resources development through employee management and development enables organizations to achieve their competitive priorities. In effect, if manufacturers focus on different competitive priorities, do these choices influence their operating practices with respect to employee management and development? Secondly, although the importance of employees and human resource (HR) practices to organizational productivity and performance is well established [15,16], there is evidence to suggest that employee management and development is not a key priority of Asian organizations. For example, a study by Mann et al. [17] found that employee skills, development and training were considered an important long-term priority by only $25 \%$ of Asian organizations. In addition, a study of the Association of Southeast Asian Nations (ASEAN) manufacturers identified a lack of focus on employee involvement as well as low levels of people management [18]. Therefore, it is important to understand if adopting specific competitive priorities can influence better employee management and development. Thirdly, there is a need for more understanding of how strategic choices affect organizational performance in developing countries [19]. In particular, the examination of organizations in the four selected countries implies that a combined view of prominent manufacturing and exporting Asian countries can be achieved. Such a multi-country investigation of strategic choices and organizational improvement in Asia is not well studied in the academic literature. Finally, it is important to understand the implications of such strategic choices for sustainability in manufacturing supply chains in the countries of interest.

This study, consequently, identifies three dimensions of competitive priorities-customer focus, product innovation and delivery-and investigates their individual relationships with an organizational focus on employee management and development. This study then investigates the relationships between employee management/development and three dimensions of organizational performance-quality performance, production flexibility and operations cost. Therefore, the study examines if employee management and development can relate differently to different aspects of operational performance. The need to examine different aspects of organizational performance was motivated by the realization that different human resource management strategies can be linked to different manufacturing performance outcomes [20]. Furthermore, given the earlier argument that employee management and development enables an organization to achieve their competitive priorities, it is important to understand if it also mediates the relationships between competitive priorities and organizational performance.

Competitive priorities have been described as the strategic choices that organizations make to enable them to compete against rival organizations and gain a competitive advantage [21]. The competitive priorities literature has examined several aspects of the nature and application of competitive priorities. While publications such as Hayes and Wheelwright [21] identified competitive strategies dimensions such as quality, lead time, cost and flexibility, other publications such as Cai and 
Yang [13], focused on the need to align competitive priorities with other organizational aspects such as the business environment. In addition, while the literature on competitive priorities has traditionally focused on manufacturing organizations, there is evidence that its applications are now being extended to the service industry in different countries [22,23].

There has been much debate in the extant literature about what constitutes competitive priorities. In addition to the four dimensions mentioned in the preceding paragraph, the study by Thürer et al. [24], identified cost, quality, delivery, flexibility and innovativeness as dimensions of competitive priorities. Foo and Friedman [25] further suggested 'service' and 'manufacturing technology' as two dimensions of competitive priorities that could be added to the four suggested by Hayes and Wheelwright [21]. The dimension of delivery has also been promoted by studies such as Kathuria et al. [26] and Ward et al. [27], while innovativeness was also highlighted by Leong et al. [28]. However, other studies such as Phusavat and Kanchana [22] and Verma and Young [29] have, in addition to some of the above, identified competitive priorities to include customer focus, service provision and employees.

For this study, three dimensions of competitive priorities are adopted-customer focus, product innovation and delivery. While the study of Phusavat and Kanchana [22] identified customer focus as one of the key competitive priorities of organizations in Thailand, based on the service industry, there is evidence to show that customer focus was also important in the manufacturing industry, particularly in Asia. Customers' demands should be taken into consideration when making a decision on the provision of products or services [30-32]. A study by Laosirihongthong et al. [33] found that manufacturers in the ASEAN automotive industry attached more importance to success in maintaining good contacts and relationships with supply chain partners in comparison to system-based factors. Specifically, the study found that higher performing manufacturers were better at and attached more importance to customer-related activities, in comparison to lower performing manufacturers. This study, therefore, is one of the few studies to investigate the impacts of customer focus as a competitive priority within the context of manufacturing organizations.

In addressing three different dimensions of competitive priorities, this study sought to find out if there were differences on the emphasis placed on any of the three competitive priorities. It has been argued in the literature that it is challenging for organizations to excel at multiple competitive priorities at any one time [34]. The implication, therefore, is that there will be one dominant competitive priority at any particular time.

\subsection{Employee Management and Development}

The relationship between strategy and human resource development is well established in the literature. According to Sanz-Valle et al. [35], human resources serve a dual purpose of enabling strategy implementation and act as a source of competitive advantage. The suggestion, therefore, is that human resources have a strong link with the other two dimensions of this study-competitive priorities (strategy) and manufacturing performance (competitive advantage). Numerous studies on human resource management have sought to examine if certain human resource actions are more suited to particular business strategies [36-38]. The implication is, therefore, that for a particular strategic objective to be achieved, specific human resource activities need to be prioritized. Among human resources activities, the management and development of employees have received some attention in the literature. The development of human resources is typically carried out to improve the capabilities of employees to enable them to achieve a desired performance [39-43]. Specific interventions that have been identified as central to the development of employees and their competencies include training, career development and performance appraisal [44]. In addition to the development of employees, other studies have highlighted the importance of employee management through managerial actions. Jayaram et al. [20] identified practices such as top management commitment, the communication of goals, employee autonomy, and effective labor management relations as important factors that affect manufacturing performance and competitive advantage. A separate study by Kathuria and Partovi [14] classified employee management activities into three groups of relationship-oriented 
practices, work-oriented practices and participative leadership and delegation and the study found that they had a variable impact on manufacturing flexibility.

Therefore, the conclusion from the literature is that human resource (HR) factors such as employee management and development are strongly associated with competitive priorities and organizational performance. However, the relationships are complex and non-trivial as different competitive priorities do not associate equally with different HR factors, and similarly, different HR factors motivate different organizational performance measures differently. Therefore, this study contributes to a greater understanding of this multi-dimensional picture by considering three specific competitive priorities and three specific manufacturing performance perspectives and evaluating their relationship with employee management and development.

\subsection{Theoretical Perspective of the Resource-Based View}

Resource-based view (RBV) theory proposes that organizations can improve their levels of performance and competitiveness if they are able to develop certain resources or capabilities which will provide them with a competitive edge $[45,46]$. The theory further specifies that such resources or capabilities should be valuable, rare, inimitable and non-substitutable [47]. Resources can be either tangible or intangible assets and capabilities are the ability to exploit and combine resources effectively [48]. The human resource capabilities of an organization are commonly accepted to be suitable for RBV research [49,50], and many of its activities can be central to the core competencies of an organization [51]. Within the context of this study, it is suggested that employee management and development is unique to each organization and as such, is considered as a competency that may be leveraged to enable the competitive edge. Peteraf [52] affirmed that leveraging RBV resources and competencies distinctively can result in gaining competitive advantage. RBV, therefore, is a suitable theory to underpin this study.

This study aims to identify the ability of different competitive priorities to enable sustainable manufacturing performance by motivating Asian manufacturers to develop their human resources. This study is of particular relevance and importance to Asian manufacturers faced with determining their strategic direction and optimizing investment decisions in order to achieve a sustainable performance in an increasingly uncertain business environment. Furthermore, motivating employees to enable sustainable performance will become an imperative in the business world and an identification of the competitive priorities that may or may not enable such outcomes is important in strategic decision making.

\section{Hypotheses}

\subsection{Competitive Priorities and Employee Management and Development}

Competitive priorities, being an aspect of operations strategy, have been linked to various operational aspects of the endeavor. For example, Drohomeretski et al. [53] stressed that there is an important relationship between competitive priorities and the deployment of lean manufacturing activities while Boyer and McDermott [54] cautioned that for competitive priorities to be successful, they need to be aligned with the resources deployed by the organization. This view was further stressed in a later study by Liu and Liang [55], which identified negative effects on the competitive advantage as a consequence of poor alignment between competitive priorities and resource deployment. A key resource of many organizations is their human resources, and the way in which this resource is managed and developed will impact on its effectiveness. As has been identified by Phusavat and Kanchana [22] and Verma and Young [29], customer focus is an important competitive priority. Hence, it is important to see if this competitive priority influences the human resource activity of employee management and development. Therefore, for Asian manufacturers with a competitive priority that is a focus on customers, the following is hypothesized: 
Hypothesis 1 (H1). A competitive priority of customer focus will have a positive influence on employee management and development.

Product innovation refers to the development of new products by exploiting new technologies, features and technologies [56,57]. New product features and characteristics have also been identified by Thompson et al. [58] as components of a strategic approach that companies adopt to differentiate themselves in the market. However, such a strategic approach needs to be implemented by the deployment of resources [59]. With particular respect to product innovation, human resources and the way they are managed and deployed are central to success. This is because innovation requires the exploitation of the knowledge and skills of employees within the organization [60], and leaders in such organizations need to ensure that a supportive environment that supports employee innovation is evident [61]. In addition, the need to further understand the dimensions of product innovation within the context of developing countries has been recognized in the literature $[62,63]$. Therefore, it is important to investigate if Asian manufacturers that focus on product innovation use this a basis for human resource development. Consequently, the following is hypothesized:

Hypothesis 2 (H2). A competitive priority of product innovation will have a positive influence on employee management and development.

Delivery operations are an important part of modern business consideration and strategy. According to Laosirihongthong et al. [33], organizations face intense global pressures to improve their delivery performance, and this pressure has manifested in a re-examination of strategic priorities. Delivery has been well recognized as an important competitive priority $[24,27,64]$. In addition, a study of Indian organizations found that delivery was one of the two most important competitive priorities. There have also been attempts to investigate the relationship between delivery as a competitive priority and human resource as an organizational resource. For example, a study of Chinese organizations by Cai and Yang [13] found that delivery priority was adopted when organizations were facing labor challenges. Given that delivery is an established competitive priority and human resources is a key resource to enable strategic options, it is important to understand if the adoption of delivery as a competitive priority has an impact on the way organizations manage and develop their human resources, the following is hypothesized:

Hypothesis 3 (H3). A competitive priority of delivery will have a positive influence on employee management and development.

\subsection{The Importance of Employee Management and Development to Manufacturing Performance}

Employees are an important resource to any organization and therefore attention has to be paid to how this human resource is developed. The importance of employees was stressed by Guillon and Cezanne [65], who noted that the involvement and participation of employees is a dependent factor for economic performance. A similar view was expressed by other studies including Almatrooshi et al. [65], Alagaraja et al. [66], Sarfaraz et al. [67] and Melián-González et al. [68] who posit that the performance of an organization depends on its employees and their satisfaction. However, achieving performance expectations requires an organization to implement effective people management and development [69] or soft total quality management (TQM) [70]. From the RBV perspective, effective people management and development can be a unique organizational competency that could lead to a competitive advantage. In effect, organizations need to pay particular attention to the activities and approaches that relate to the management of their human resource. According to Sanz-Valle et al. [35], human resource management (HRM) not only plays a role in strategy implementation but how an organization manages its employees is critical to the success of the organization. HRM, therefore, should involve directing and engaging employees [71]. Oakland and Oakland [69] went further to suggest that the effective management of people should involve factors such as teamwork, communication, 
empowerment and training. In addition, Hanna et al. [72] identified employee involvement as an important factor to be focused on to enable performance success while Thanyawatpornkul et al. [73] stressed the importance of reward and recognition in the successful execution of strategy. The variety of potential aspects of suggested activities implies that organizations need to approach employee management and development from a holistic view.

Although there has been strong literature support for the important relationship between HRM and organizational performance, the measurement of organizational performance is neither simple nor straightforward. A study by Lee et al. [16] suggested that there are different ways to define organizational performance and identified the dimensions used in previous research which include the following: productivity, efficiency, employee turnover, quality, customer satisfaction, absenteeism, cost, delivery, flexibility and efficiency. This variety of ways in which organizational performance can be measured leads to a consideration of whether employee management and development affects all of these dimensions of performance in the same way. The evidence from the literature suggests otherwise. A study by Jayaram et al. [20] found that different HRM practices had different levels of impact on four different measures of performance-cost, quality, flexibility and time. Similarly, Kathuria and Partovi [14] noted that relationship-leaning HR practices such as team building, inspiring, recognizing, delegation and participative leadership were particularly important if the organizational emphasis was on flexibility.

For the purposes of this research, three dimensions of organizational performance were chosenquality performance, production flexibility and operations cost. The choice of these three was based on the review by Ward et al. [27] which found that previous studies have mostly considered generic manufacturing priorities to be cost, quality, flexibility and delivery. A similar conclusion was reached by Lee et al. [16] which espoused that there are three commonly accepted dimensions of organizational performance-product quality, product delivery and production cost. These factors have also been found to be important factors in the drive to be more environmentally sustainable since quality, flexibility and cost have been identified as key influencers in the decisions of manufacturing organizations to deploy sustainable supply chain practices [74]. In addition, a study by Ahmad and Schroeder [75] which investigated the impact of HRM practices on operational performance suggested that the cost, quality, flexibility, delivery and the speed of new product introduction are important tangible measures.

Consequently, based on the indication from the literature that HRM practices impact organizational performance and the choice of performance measures used in this study, the following are hypothesized:

Hypothesis 4 (H4). Employee management and development will have a positive influence on quality performance.

Hypothesis 5 (H5). Employee management and development will have a positive influence on production flexibility.

Hypothesis 6 (H6). Employee management and development will have a positive influence on operations cost.

Figure 1 shows the conceptual model for this study and indicates the relationships between the variables to be studied in this research. The next section presents the methodology adopted to investigate these relationships. 


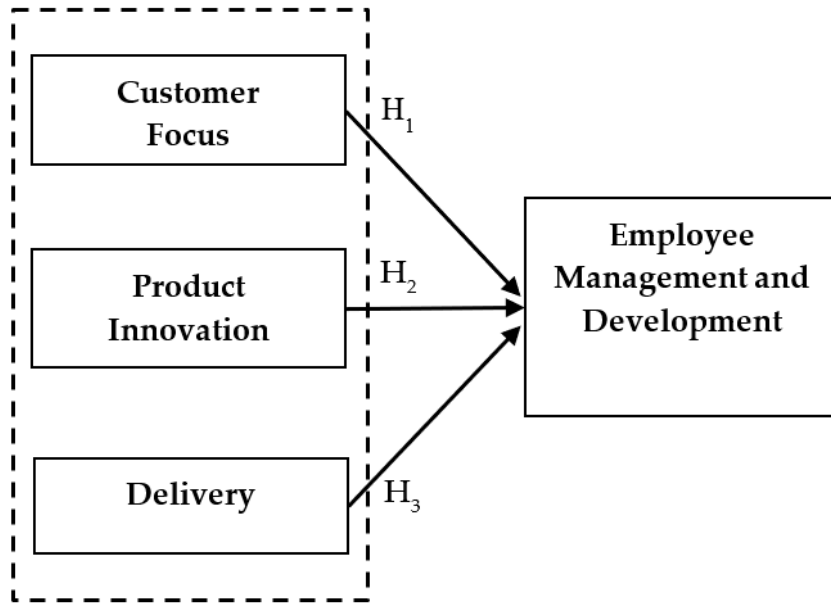

Competitive Priorities

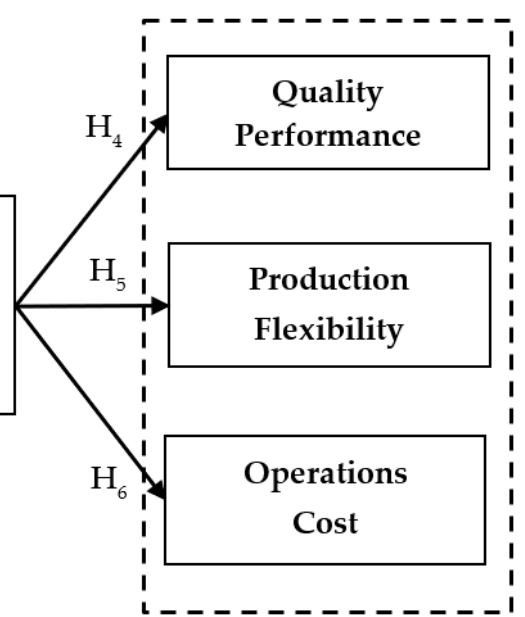

Manufacturing Performance

Figure 1. Research Model.

\section{Materials and Methods}

\section{Measures and Data Collection}

Table 1 shows the scales, measurement items and references of this study. The survey items of competitive priority of customer focus, product innovation and delivery were adapted from Miller and Roth [10] and Cagliano et al. [76]. These three scales were assessed for the importance of attributes to win orders from major customers using a five-point Likert scale where 1 represents not important and 5 represents very important. The scale of employee management and development was measured using four measurement items adapted from Cagliano et al. [77], Sveiby and Simons [78], Rogg et al. [79] and Cagliano et al. [80]. This variable was assessed for effort in the current level of implementation using a five-point Likert scale where the anchors were $1=$ none and $5=$ high. Two survey items were adapted from past studies $[34,81-85]$ to measure the level of quality performance. The scale of production flexibility was adapted from Jack and Raturi [86] and Hallgren and Olhager [87]. The three measurement items of operational cost were adapted from Ferdows and Meyer [34], Woo et al. [88] and Rao [89]. All responses for quality performance, production efficiency and operational cost (i.e., compared to the main competitors) were captured using a five-point Likert scale where 1 represents much higher and 5 represents much lower.

Table 1. Constructs and survey items.

\begin{tabular}{|c|c|c|}
\hline Constructs & Survey Items & Source \\
\hline $\begin{array}{l}\text { A Competitive Priority } \\
\text { of Customer Focus }\end{array}$ & $\begin{array}{l}\text { Consider the importance of the following attributes to win } \\
\text { orders from your major customers. (Importance in the last } \\
\text { three years: } 1=\text { not important; } 5=\text { very important) } \\
\text { 1. Better conformance to customer specifications; } \\
\text { 2. Superior customer service (training, information, } \\
\text { help-desk); } \\
\text { 3. Superior product assistance/support (after-sales and/or } \\
\text { technical support). }\end{array}$ & $\begin{array}{l}\text { Miller and Roth [10], } \\
\text { Cagliano et al. [76] }\end{array}$ \\
\hline $\begin{array}{l}\text { A Competitive Priority } \\
\text { of Product Innovation }\end{array}$ & $\begin{array}{l}\text { Consider the importance of the following attributes to win } \\
\text { orders from your major customers. (Importance in the last } \\
\text { three years: } 1=\text { not important; } 5=\text { very important) } \\
\text { 1. Better product design and quality; } \\
\text { 2. Wider product range; } \\
\text { 3. Offer new products more frequently; } \\
\text { 4. Offer products that are more innovative. }\end{array}$ & $\begin{array}{l}\text { Miller and Roth [10], } \\
\text { Cagliano et al. [76] }\end{array}$ \\
\hline
\end{tabular}


Table 1. Cont.

\begin{tabular}{|c|c|c|}
\hline Constructs & Survey Items & Source \\
\hline $\begin{array}{l}\text { A Competitive Priority } \\
\text { of Delivery }\end{array}$ & $\begin{array}{l}\text { Consider the importance of the following attributes to win } \\
\text { orders from your major customers. (Importance in the last } \\
\text { three years: } 1=\text { not important; } 5 \text { = very important) } \\
\text { 1. Faster deliveries; } \\
\text { 2. More reliable deliveries; } \\
\text { 3. Greater order size flexibility. }\end{array}$ & $\begin{array}{l}\text { Miller and Roth [10], } \\
\text { Cagliano et al. [76] }\end{array}$ \\
\hline $\begin{array}{l}\text { Employee Management } \\
\text { and Development }\end{array}$ & $\begin{array}{l}\text { Indicate the effort put in the current level of } \\
\text { implementation of action programs related to: } \\
\text { (Current level of implementation: } 1=\text { none; } 5=\text { high) } \\
\text { 1. Delegation and knowledge of your workers } \\
\text { (e.g., empowerment, training, encouraging solutions to } \\
\text { work-related problems, pay for competence or incentives } \\
\text { for improvement results); } \\
\text { 2. Open communication between workers and managers } \\
\text { (information sharing, encouraging bottom-up open } \\
\text { communication, two-way communication flows); } \\
\text { 3. Autonomous teams (e.g., team responsible for planning, } \\
\text { execution and control, workers sharing experience, } \\
\text { knowledge and skills, formalization of team composition } \\
\text { and responsibilities, work group incentives); } \\
\text { 4. Workers flexibility (e.g., multi-tasking, multi-skilling, } \\
\text { job rotation); } \\
\text { 5. Use of flexible forms of work (e.g., temporary workers, } \\
\text { part time, job sharing, variable working hours). }\end{array}$ & $\begin{array}{c}\text { Cagliano et al. [77], Sveiby } \\
\text { and Simons [78], } \\
\text { Rogg et al. [79], } \\
\text { Cagliano et al. [80]. }\end{array}$ \\
\hline Quality Performance & $\begin{array}{l}\text { How does your current performance compare with that of } \\
\text { your main competitor(s) }{ }^{1} \text { ? } \\
{ }^{1} \text { Consider the average performance of the group of } \\
\text { competitors that are the direct benchmark for the plant. } \\
\text { (Relative to our main competitors, our performance is: } \\
1=\text { much lower; } 2 \text { = lower; } 3=\text { equal; } 4=\text { higher; } \\
5=\text { much higher) } \\
\text { 1. Conformance quality; } \\
\text { 2. Product quality and reliability. }\end{array}$ & $\begin{array}{l}\text { Sitkin et al. [81], Garvin [82], } \\
\text { Forza and Filippini [83], } \\
\text { Ferdows and Meyer [34], } \\
\text { Ahmed [84], } \\
\text { Kimura et al. [85]. }\end{array}$ \\
\hline Production Flexibility & $\begin{array}{l}\text { How does your current performance compare with that of } \\
\text { your main competitor(s) }{ }^{1} \text { ? } \\
{ }^{1} \text { Consider the average performance of the group of } \\
\text { competitors that are the direct benchmark for the plant. } \\
\text { (Relative to our main competitors, our performance is: } \\
1=\text { much lower; } 2 \text { = lower; } 3=\text { equal; } 4=\text { higher; } \\
5=\text { much higher) } \\
\text { 1. Volume flexibility; } \\
\text { 2. Mix flexibility. }\end{array}$ & $\begin{array}{l}\text { Jack and Raturi [86], } \\
\text { Hallgren and Olhager [87]. }\end{array}$ \\
\hline Operations Cost & $\begin{array}{l}\text { How does your current performance compare with that of } \\
\text { your main competitor(s) }{ }^{1} \text { ? } \\
{ }^{1} \text { Consider the average performance of the group of } \\
\text { competitors that are the direct benchmark for the plant. } \\
\text { (Relative to our main competitors, our performance is: } \\
1=\text { much higher; } 2 \text { = higher; } 3 \text { = equal; } 4 \text { = lower; } \\
5=\text { much lower) } \\
\text { 1. Unit manufacturing cost; } \\
\text { 2. Ordering cost; } \\
\text { 3. Materials, water and/or energy consumption. }\end{array}$ & $\begin{array}{l}\text { Ferdows and Meyer [34], } \\
\text { Woo et al. [88], Rao [89]. }\end{array}$ \\
\hline
\end{tabular}

Data from the sixth edition of the International Manufacturing Strategy Survey (IMSS) [90] were analyzed to test the research hypotheses. The survey of the sixth version of the IMSS was carried out between July 2013 and June 2014, with the participation of leading institutions in 23 different countries. This global research collected the primary data from the first-line, middle and top managers of the manufacturing companies listed in the International Standard Industrial Classification (ISIC) Revision four codes ranging from 25 (manufacture of fabricated metal products, except machinery 
and equipment), 26 (manufacture of computer, electronic and optical products), 27 (manufacture of electrical equipment), 28 (manufacture of machinery and equipment not elsewhere classified), 29 (manufacture of motor vehicles, trailers and semi-trailers) to 30 (manufacture of other transport equipment). To ensure data consistency and comparability, a self-administered survey questionnaire was used and the data collection procedures across the different countries were centrally coordinated through spreadsheets and survey monkey cloud-based software.

Two sampling methods (i.e., random and purposive samplings) were employed in the data collection. In the random sampling, all the country coordinators formed a sampling frame of the population of the manufacturing companies using their national databases. The target sample only involved companies with ISIC codes between 25 and 30 as well as with an employee population of over 50. Each country's coordinator randomly selected the companies from the respective sampling frame for data collection. In the purposive sampling, the country coordinators were required to contact companies that participated in previous IMSS projects. The reason was IMSS was a longitudinal global project (IMSS I in 1992-1994; IMSS II in 1996-1998; IMSS III 2000-2002; IMSS IV in 2005; IMSS V in 2010). All the country coordinators who were involved in previous IMSS editions were encouraged to contact all the companies that were indexed in the previous database.

\section{Results}

Prior to all the survey distribution of the sixth version of the IMSS, the country coordinators were required to contact the potential research participants and obtain their consent to take part in the study. All data were systematically checked and validated for non-response bias and late-response bias before the final release of the IMSS data set by Politecnico di Milano (Italy) in September 2014. For the non-response bias test, all the country coordinators assessed the $t$-test and $\chi^{2}$ test with the figures of sales, number of employees and SIC code for respondents and non-respondents. For the late-response bias test, all the country coordinators conducted the t-test and $\chi^{2}$ test using the figures of sales, number of employees and SIC code for early respondents and late respondents.

The common method biasness of the responses was also checked through Harman's single-factor test. Unrotated principal component factor analysis using the eigenvalue-greater-than-one criterion generated six factors. These factors accounted for $66.68 \%$ of the variance. The factor with the greatest eigenvalue accounted for $27.28 \%$ of the variance. Given that no single factor emerged as a dominant, the common method bias is not a major concern in this study.

For the purpose of this study, a total of 259 data sets were analyzed. The sample included 127 (49 percent) from China, 91 (35.1 percent) from India, 28 (10.8 percent) from Taiwan and 13 (5 percent) from Malaysia. In terms of the ISIC code, 46 (17.8 percent) companies were registered with ISIC 25, 69 (26.6 percent) with ISIC 26, 40 (15.4 percent) with ISIC 27, 53 (20.5 percent) with ISIC 28, 36 (13.9 percent) with ISIC 29 and the remaining 15 (5.8 percent) with ISIC 30. All the respondents were either first-line, middle or top managers whose job titles included chief executive officers (CEO), vice presidents, directors, general managers, operations manager, plant managers, senior engineers and technical lead. In terms of years of experience in operations/manufacturing in the organization, 42 (16.2 percent) respondents had less than three years of experience, 185 (71.4 percent) respondents had more than 3 years of experience and 32 (12.4 percent) respondents did not specify their working experience. Table 2 shows the demographic characteristics of the respondents. 
Table 2. Demographic characteristics of the sample.

\begin{tabular}{|c|c|c|c|}
\hline Variables & Descriptions & Frequency $(n=259)$ & Percent $(\mathbf{1 0 0 \% )}$ \\
\hline \multirow{4}{*}{ Countries } & China & 127 & 49.0 \\
\hline & India & 91 & 35.1 \\
\hline & Taiwan & 28 & 10.8 \\
\hline & Malaysia & 13 & 5.0 \\
\hline \multirow{6}{*}{$\begin{array}{l}\text { International Standard } \\
\text { Industrial Classification } \\
\text { Code of Companies }\end{array}$} & $\begin{array}{l}\text { 25: Manufacture of fabricated metal products, } \\
\text { except machinery and equipment }\end{array}$ & 46 & 17.8 \\
\hline & $\begin{array}{l}\text { 26: Manufacture of computer, electronic and } \\
\text { optical products }\end{array}$ & 69 & 26.6 \\
\hline & 27: Manufacture of electrical equipment & 40 & 15.4 \\
\hline & $\begin{array}{l}\text { 28: Manufacture of machinery and equipment } \\
\text { not elsewhere classified }\end{array}$ & 53 & 20.5 \\
\hline & $\begin{array}{l}\text { 29: Manufacture of motor vehicles, trailers and } \\
\text { semi-trailers }\end{array}$ & 36 & 13.9 \\
\hline & 30: Manufacture of other transport equipment & 15 & 5.8 \\
\hline \multirow{6}{*}{ Job Title } & Chief Executive Officer/Chief Financial & & \\
\hline & $\begin{array}{l}\text { Officer/Chief Information Officer } \\
\text { /President/Chairman }\end{array}$ & 26 & 10.0 \\
\hline & Vice President/Director/General Manager & 65 & 25.1 \\
\hline & Managers & 107 & 41.3 \\
\hline & Senior Engineer/Technical Lead & 33 & 12.7 \\
\hline & Other & 28 & 10.8 \\
\hline \multirow{8}{*}{$\begin{array}{l}\text { Years of Experience in } \\
\text { Operations/Manufacturing } \\
\text { in the Organization }\end{array}$} & Below 3 years & 42 & 16.2 \\
\hline & $3-5$ years & 47 & 18.1 \\
\hline & $6-10$ years & 68 & 26.2 \\
\hline & $11-15$ years & 32 & 12.4 \\
\hline & $16-20$ years & 23 & 8.9 \\
\hline & $21-30$ years & 10 & 3.9 \\
\hline & Above 30 years & 5 & 1.9 \\
\hline & Unspecified & 32 & 12.4 \\
\hline
\end{tabular}

\subsection{Data Validation}

Principal component exploratory factor analysis was conducted to check for the underlying structure among the variables. Table 3 shows the results of the factor analysis of the studied variables. All the survey items had high factor loadings between 0.649 and 0.934 , greater than the suggested value of 0.50 [91]. To assess the reliability, both Cronbach's Alpha and composite reliability were assessed (see Table 4). The coefficients of Cronbach's Alpha of all variables were high and well above the recommended threshold of 0.70 [91]. Likewise, the values of composite reliability, ranging from 0.840 to 0.932 , were greater than the desirable value of 0.60 [92]. Convergent validity was assessed using the average variance extracted (AVE). Every variable had AVE ranging from 0.577 to 0.872 , meeting the threshold of 0.50. Referring to Table 5, discriminant validity was established as the coefficients of the square roots of AVE were higher than the off-diagonal measures in the correlation matrix [93]. Taken together, these results indicate strong reliability and construct validity.

Table 3. Results of factor analysis.

\begin{tabular}{cccccccccc}
\hline \multirow{2}{*}{ Variables } & \multirow{2}{*}{ No. of Items } & \multirow{2}{*}{ KMO } & \multirow{2}{*}{ BTS } & \multirow{2}{*}{ EV } & \multicolumn{5}{c}{ Factor Loadings } \\
\cline { 6 - 10 } & & & & & Item 1 & Item 2 & Item 3 & Item 4 & Item 5 \\
\hline CF & 3 & 0.591 & $190.963^{* * *}$ & 1.919 & 0.652 & 0.887 & 0.841 & Nil & Nil \\
PI & 4 & 0.756 & $323.084^{* * *}$ & 2.491 & 0.683 & 0.825 & 0.832 & 0.807 & Nil \\
DE & 3 & 0.585 & $196.500^{* * *}$ & 1.924 & 0.841 & 0.892 & 0.649 & Nil & Nil \\
EMD & 5 & 0.795 & 442.974 & 2.886 & 0.807 & 0.779 & 0.800 & 0.727 & 0.678 \\
QP & 2 & 0.500 & $208.846^{* * *}$ & 1.746 & 0.934 & 0.934 & Nil & Nil & Nil \\
PF & 2 & 0.500 & $189.426^{* * *}$ & 1.723 & 0.928 & 0.928 & Nil & Nil & Nil \\
OC & 3 & 0.634 & $232.856^{* * *}$ & 2.039 & 0.866 & 0.886 & 0.709 & Nil & Nil \\
\hline
\end{tabular}

Note: ${ }^{* * *} p<0.001 ; \mathrm{KMO}=$ Kaiser-Meyer-Olkin; BTS = Barlett's test of sphericity; EV = eigenvalues; CF = customer focus; $\mathrm{PI}=$ product innovation; $\mathrm{DE}=$ delivery; $\mathrm{EMD}=$ employee management and development; $\mathrm{QP}=$ quality performance; $\mathrm{PF}=$ production flexibility; $\mathrm{OC}=$ operations cost. 
Table 4. Results of the descriptive, reliability and the validity analyses.

\begin{tabular}{cccccc}
\hline & Mean & $\begin{array}{c}\text { Standard } \\
\text { Deviation }\end{array}$ & $\begin{array}{c}\text { Cronbach's } \\
\text { Alpha }\end{array}$ & $\begin{array}{c}\text { Composite } \\
\text { Reliability }\end{array}$ & $\begin{array}{c}\text { Average Variance } \\
\text { Extracted }\end{array}$ \\
\hline Customer Focus & 4.058 & 0.928 & 0.709 & 0.840 & 0.640 \\
Product Innovation & 3.873 & 0.912 & 0.798 & 0.868 & 0.623 \\
Delivery & 3.996 & 0.887 & 0.701 & 0.841 & 0.641 \\
Employee Management and Development & 3.599 & 0.783 & 0.807 & 0.872 & 0.577 \\
Quality Performance & 3.778 & 0.806 & 0.855 & 0.932 & 0.872 \\
Production Flexibility & 3.475 & 0.763 & 0.838 & 0.925 & 0.861 \\
Operations Cost & 3.116 & 0.764 & 0.761 & 0.863 & 0.679 \\
\hline
\end{tabular}

Table 5. Results of the correlation analysis of the Asian sample.

\begin{tabular}{cccccccc}
\hline & CF & PI & DE & EMD & QP & PF & OC \\
\hline CF & $\mathbf{0 . 8 0 0}$ & & & & & & \\
PI & $0.510^{* *}$ & $\mathbf{0 . 7 8 9}$ & & & & & \\
DE & $0.452^{* *}$ & $0.507^{* *}$ & $\mathbf{0 . 8 0 1}$ & & & & \\
EMD & $0.219^{* *}$ & $0.254^{* *}$ & $0.254^{* *}$ & $\mathbf{0 . 7 6 0}$ & & & \\
QP & 0.072 & $0.249^{* *}$ & 0.115 & $0.291^{* *}$ & $\mathbf{0 . 9 3 4}$ & & \\
PF & $0.128^{*}$ & $0.370^{* *}$ & $0.238^{* *}$ & $0.282^{* *}$ & $0.607^{* *}$ & $\mathbf{0 . 9 2 8}$ & \\
OC & 0.056 & 0.074 & 0.035 & $0.208^{* *}$ & $0.140^{*}$ & $0.241^{* *}$ & $\mathbf{0 . 8 2 4}$ \\
\hline
\end{tabular}

Note: * Correlations are significant at the 0.05 level (2-tailed); ${ }^{* *}$ Correlations are significant at the 0.01 level (2-tailed); Bold values in the diagonal row are square roots of the average variance extracted (AVE); EMD = employee management and development; $\mathrm{CF}=$ customer focus; $\mathrm{PI}=$ product innovation; $\mathrm{DE}=$ delivery; $\mathrm{QP}=$ quality performance; $\mathrm{PF}=$ production flexibility; $\mathrm{OC}=$ operations cost.

The research hypotheses were tested using structural equation modeling (SEM) via the analysis of moment structures (AMOS) 20.0. The model fit was assessed using absolute and incremental fit indices, namely the normed chi square (NC), goodness-of-fit (GFI) index, adjusted goodness-of-fit (AGFI) index, root mean square error of approximation (RMSEA), normed fit index (NFI), Tucker Lewis index (TLI), and the comparative fit index (CFI). In this study, the SEM results show a good model fit with $\mathrm{NC}=1.027, \mathrm{GFI}=0.943, \mathrm{AGFI}=0.916, \mathrm{RMSEA}=0.010, \mathrm{RMR}=0.049, \mathrm{NFI}=0.935, \mathrm{TLI}=0.997$, and CFI $=0.998$. As shown in Table 6, the hypothesis testing results of the model indicate that a competitive priority of customer focus has an insignificant relationship with employee management and development $(\beta=0.006$; $p$-value $>0.05)$. As hypothesized, a competitive priority of product innovation has a significant and positive impact on employee management and development $(\beta=0.314$; $p$-value $<0.01)$. However, a competitive priority of delivery has an insignificant relationship with employee management and development $(\beta=0.157 ; p$-value $>0.05)$. From the aspect of manufacturing performance, employee management and development have a significant and positive influence on quality performance $(\beta=0.448 ; p$-value $<0.001)$, production flexibility $(\beta=0.347 ; p$-value $<0.001)$ and operation $\operatorname{cost}(\beta=0.222 ; p$-value $<0.01)$. The results provide evidence to support $\mathrm{H} 2, \mathrm{H} 4, \mathrm{H} 5$ and $\mathrm{H} 6$. However, $\mathrm{H} 1$ and $\mathrm{H} 3$ were not empirically supported.

Table 6. Results of the structural equation modeling analysis.

\begin{tabular}{|c|c|c|c|c|c|}
\hline Hypotheses & Causal Path & $\begin{array}{l}\text { Standard Path } \\
\text { Coefficients }\end{array}$ & $\begin{array}{l}\text { Standard } \\
\text { Errors }\end{array}$ & $\begin{array}{l}\text { Critical } \\
\text { Ratios }\end{array}$ & $p$-Value \\
\hline H1 & Customer Focus $\rightarrow$ Employee Management and Development & 0.006 & 0.167 & 0.088 & 0.930 \\
\hline $\mathrm{H} 2$ & $\begin{array}{c}\text { Product Innovation } \rightarrow \text { Employee Management } \\
\text { and Development }\end{array}$ & 0.314 & 0.170 & 3.043 & $0.002 * *$ \\
\hline $\mathrm{H} 3$ & Delivery $\rightarrow$ Employee Management and Development & 0.157 & 0.079 & 1.653 & 0.098 \\
\hline $\mathrm{H} 4$ & $\begin{array}{c}\text { Employee Management and Development } \rightarrow \\
\text { Quality Performance }\end{array}$ & 0.448 & 0.076 & 6.293 & $0.000 * * *$ \\
\hline H6 & Employee Management and Development $\rightarrow$ Operations Cost & 0.222 & 0.073 & 3.039 & $0.002 * *$ \\
\hline
\end{tabular}




\subsection{Mediation Effect of Employee Management and Development}

The significant positive relationship between the competitive priority of product innovation and employee management and development resulted in the testing of a mediating effect for employee management and development (see Figure 2). Since product innovation was the only competitive priority to have a significant relationship with employee management and development, the relationships with the other two competitive priorities did not need to be tested. The mediating relationships was tested using the bootstrap approach [94]. In order to test the relationships, ad hoc hypotheses were developed to test the mediating relationships with the three performance constructs. The ad hoc hypotheses proposed to test the mediating relationships are as follows:

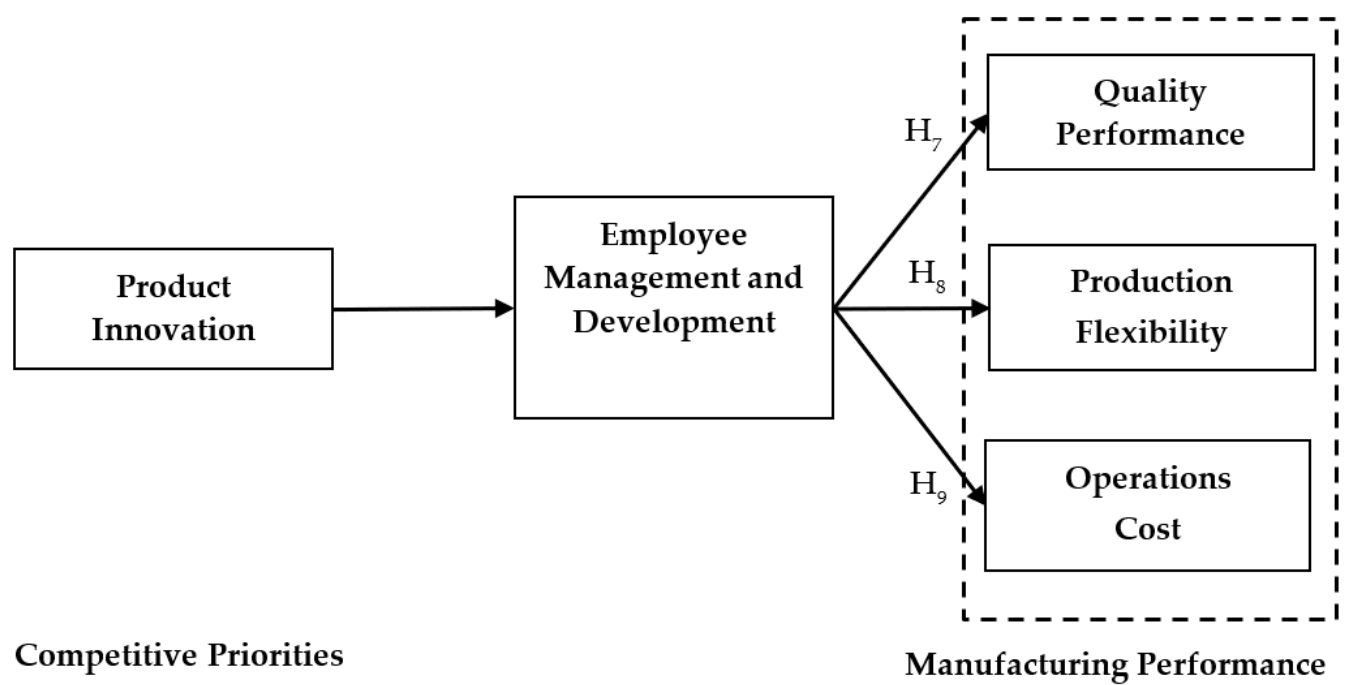

Figure 2. Research model for indirect effects.

Hypothesis 7 (H7). Employee management and development will partially mediate the relationship between the competitive priority of product innovation and quality performance.

Hypothesis 8 (H8). Employee management and development will partially mediate the relationship between the competitive priority of product innovation and production flexibility.

Hypothesis 9 (H9). Employee management and development will partially mediate the relationship between the competitive priority of product innovation and operation cost.

The indirect effect of employee management and development on quality performance was calculated as the product of the path coefficients between the competitive priority of product innovation and employee management and development $(\beta=0.314)$ and between employee management and development and quality performance $(\beta=0.448)$. This indirect effect coefficient was equal to 0.141 , which can be validated for significance using the bootstrap approach. Likewise, the indirect effect of employee management and development on production flexibility was computed as the product of the path coefficients between the competitive priority of product innovation and employee management and development $(\beta=0.314)$ and between employee management and development and production flexibility $(\beta=0.347)$, resulting in a value of 0.109 . The indirect effect coefficient of employee management and development on operation cost is 0.070 , from the product of the path coefficients between the competitive priority of product innovation and employee management and development $(\beta=0.314)$ and between employee management and the development and operation $\operatorname{cost}(\beta=0.222)$. The results of bootstrapped tests are presented in Table 7 . The indirect effects were significant given that the lower confidence interval of the bias-corrected bootstrap does not contain 
zero. As both indirect and indirect effects were significant, the partial mediating effects were supported for employee management and development for a competitive priority of product innovation and manufacturing performance (i.e., quality performance, production efficiency and operation cost). As a result, $\mathrm{H} 7, \mathrm{H} 8$ and $\mathrm{H} 9$ were statistically supported.

Table 7. Bootstrap results for indirect effects.

\begin{tabular}{cccc}
\hline Construct & Estimate & Lower 95\% Confidence Interval & Upper 95\% Confidence Interval \\
\hline $\begin{array}{c}\text { Employee Management } \\
\text { and Development }\end{array}$ & & & 0.228 \\
$\begin{array}{c}\text { (Between Competitive Priority of } \\
\text { Product Innovation and } \\
\text { Quality Performance) }\end{array}$ & 0.141 & 0.040 & \\
Employee Management & & & 0.228 \\
$\quad$ and Development & & & \\
$\begin{array}{c}\text { (Between Competitive Priority of } \\
\text { Product Innovation and } \\
\quad \text { Production Flexibility) }\end{array}$ & 0.109 & 0.034 & \\
$\begin{array}{c}\text { Employee Management and } \\
\text { Development (Between }\end{array}$ & & & 0.175 \\
$\begin{array}{c}\text { Competitive Priority of Product } \\
\text { Innovation and Operations Cost) }\end{array}$ & 0.070 & & \\
\hline
\end{tabular}

\section{Discussion}

This study set out to identify the relationships between competitive priorities and employee management and development, and the subsequent relationships between employee management and development, and manufacturing performance. The study context of four Asian countries provides contributions and interesting insights into how manufacturing organizations in the countries examined manage the issues investigated within this study. The key contributions and insights from the study are discussed in this section.

\subsection{The Relationships between Competitive Priorities and Employee Management and Development}

Of the three competitive priorities examined, only product innovation had a positive influence on employee management and development. This study did not find a significant relationship between the two competitive priorities of customer focus and delivery with employee management/development. In further examining these results, the study considered if the competitive priorities of customer focus and delivery were seen as somewhat less important when compared to product innovation. However, the results shown in Table 4 indicate that the mean values of the competitive priorities of customer focus and delivery were ranked higher than product innovation. Therefore, the conclusion from these findings is that while the respondent organizations considered customer focus and delivery to be more important than product innovation when it came to winning orders from major customers, they did not consider them as factors that should drive the management and development of employees. On the contrary, the slightly less important competitive priority of product innovation was strongly linked with employee management and development. From the perspective of RBV, the findings suggest that of the three dimensions of competitive priorities, only product innovation has a strong link with the organizational competency of employee management and development. The outcomes relating to customer focus and delivery differ significantly from the assertions of previous studies. For example, Peng et al. [95] noted that emphasizing competitive priorities such as quality and delivery should be a driver of decisions relating to management practices. In addition, the study by Filho et al. [96] identified factors including teamwork, multiple skills and education as important structural areas to be developed in the pursuit of competitive priorities such as delivery. The study by Yen and Sheu [97] went further and found a medium to high association between the competitive priority of delivery and labor skills. Bourne et al. [71] also cautioned that human resource practices are central to the realization 
of the manufacturing strategy. The authors of this study would conclude by suggesting that the failure of Asian manufacturers to link customer focus and delivery priorities to employee management and development may be the outcome of the perception of the different nature of the priorities. Delivery and customer focus, while recognized as important, may have been perceived as 'routine', 'operational' or 'automated' and not particularly deserving of significant investment in staff development. Product innovation, in contrast, may have been perceived as specialist in nature and requiring a specific skillset which, in turn, requires high levels of employee management and development.

\subsection{The Relationship between Employee Management/Development and Manufacturing Performance}

This study found significant and positive relationships between employee management and development and the three manufacturing performance dimensions of quality, production flexibility and operations cost. Therefore, within the context of the Asian manufacturers surveyed, this study finds differently from the study of Chan et al. [98] which suggested that high-performance human resource practices have no significant impact on organizations in Hong Kong because the organizations were much more interested in short-term results. This divergence may be because the organizations in this study were all manufacturers compared to the multiple industry participants in the Chan et al. [98] study. The difference may also reflect specific short-termism in Hong Kong since other studies have found positive relationships between HR practices and organizational performance in multi-industry contexts $[99,100]$. The authors will suggest that manufacturing firms typically take a long-term view of their investments and that short-termism, indicated as a feature of business in Hong Kong, does not apply to manufacturers in the countries studied in this research.

On the contrary, the findings from this study suggest resonance with a variety of other studies that have identified a positive relationship between HR practice and manufacturing performance. For example, Kathuria and Partovi [14] found a positive link between employee management practices and manufacturing flexibility. Similarly, studies by Jayaram et al. [20] and Ahmad and Schroeder [75] found significant relationships between HR practices and manufacturing performance, although there were differences in the emphasis between countries, industries and HR practices. Therefore, the authors suggest that manufacturers in the four study countries have been successful in identifying and exploiting the links between their development and management of their employee resources and the results achieved in terms of quality performance, production flexibility and operations cost. From the perspective of RBV, the findings show that employee management and development is an important competency that has the potential to strongly influence multiple dimensions of organizational performance. Therefore, Asian manufacturers that wish to improve their quality, flexibility and cost competitiveness not only need to pay attention to how they develop and manage their employees but need to realize that this is an important competency to have.

\subsection{The Mediating Role of Employee Management and Development}

The mediation analysis provides support for the role of employee management and analysis as a partial mediator between product innovation and manufacturing performance. Specifically, efforts to improve product innovation impact the management and development of employee resources which, in turn, affect quality performance, production flexibility and operations cost. In effect, the ability of Asian manufacturers to manage and develop employees plays an important role in manifesting product innovation activities in terms of manufacturing performance. Theoretically, this study confirms that the adoption of product innovation competency drives the acquisition of organizational employee management and development competency leading to multi-dimensional organizational performance advantages. Hence, RBV is an applicable theory. In comparing the results to previous studies, the finding from Peng et al. [95] was that innovation capability has no significant effect on the cost or flexibility performance. However, this study suggests that when mediated by employee management and development, an indirect positive relationship does exist between product innovation manufacturing performance. 
Perhaps more importantly, the establishment of a mediating role for employee management and development as well as the strong positive links between employee management and development with manufacturing performance leads to an enquiry about why Asian manufacturers do not motivate employee management and development based on other competitive priorities examined in this study. It is clear that competitive priorities such as customer focus and delivery are important organizational considerations for Asian manufacturers but it is less clear why they do not consider that employee management and development could mediate between these competitive priorities and manufacturing performance. It may well be that these competitive priorities primarily motivate other factors (e.g., CRM systems, fleet/delivery management systems) in order to improve performance. It is also possible that while employee management and development is not influenced by the competitive priorities of customer focus and delivery, it may be motivated by other strategic factors (e.g., total quality management).

\subsection{Impact on Sustainability in Asian Manufacturers}

The three performance dimensions adopted in this study have been identified as important drivers of the desire to adopt sustainable supply chain practices [74]. This view was also supported by Kumar et al. [101]. However, the relationship between strategic choices and sustainable supply chain outcomes have also been highlighted. Specifically, Testa and Iraldo [102] proposed that the strategic choices made by an organization will impact organizational sustainability. Therefore, sustainable supply chain concerns relate strongly to both the strategic issues in the form of competitive priorities as well as performance dimensions studied in this research.

The findings of the study suggest that for Asian organizations that wish to achieve the performance outcomes studied and which have been identified as desirable outcomes of sustainable organizational activities, it will be more suitable to drive their sustainability agenda by focusing on innovation-led strategies and competitive priorities. The adoption of innovation-led competitive priorities is also the strategic approach more likely to enable the development of employees to lead to positive outcomes. In practice, the suggestion from this study is that innovative practices (e.g., product innovation or process innovation) that have positive environmental attributes are more likely to lead to the development of employees and the attainment of positive performance outcomes. In contrast, the adoption of customer-focus and delivery strategies are less likely to achieve these outcomes.

Furthermore, the results show that there is a significant positive and mediating relationship between product innovation, employee development, and manufacturing performance. The results show that both development-oriented human resources management practices and product innovation priority are required for manufacturing activities to be long term and competitive. Innovation priorities positively affect employee management and development, which increases manufacturing performance. Although developing Asian countries are essential manufacturing bases of the world economy, previous studies show that only $25 \%$ of organizations in Asia see development-oriented human resource practices as a long-term priority [17]. Although Asian organizations have a competitive advantage in manufacturing prices due to the labor prices they currently have, how sustainable it will be is a matter of discussion. The results of this study show that manufacturing performance is based on both human resources and innovation. For this reason, these two factors should be given importance for sustainable and competitive manufacturing.

\subsection{Study Implications}

The organizations studied in this research have indicated a high level of awareness and adoption of different competitive priorities as well as an understanding that investing in employee management and development can positively influence manufacturing performance. As organizations continually determine what competitive priorities to prioritize, it is crucial to understand that the choice of competitive priority may influence how much effort is expended on employee management and development and this will ultimately impact on organizational performance. However, it is important 
to understand that employee management and development should not solely be motivated by competitive priorities such as product innovation. Rather, investment in employee management and development should also encompass more routine operational considerations such as delivery and customer focus. Training programs and managerial systems in Asian manufacturers need to inculcate development activities related to a wider range of competitive priorities and other organizational strategic imperatives.

With respect to academic implications, the extant literature suggested that organizations could typically trade-off competitive priorities, but this study has shown that employee management and development has different relationships with different competitive priorities. Hence, the relationship between competitive priorities and HR could be complex and non-trivial. Furthermore, while there has been much interest in employee welfare and work practices, these do not necessarily translate into employee development for strategic purposes. From the perspective of deploying strategic initiatives, it is also important for academic research to better understand how manufacturers deploy their range of competitive priorities and how such deployment can be maximized for a competitive advantage by leveraging the right human resource factors.

\section{Conclusions}

In recent years, Asia has become a dominant manufacturing base for the world and Asian manufacturers have had to understand the importance of employees in helping them to become successful and maintain success. This study has investigated the role of employee management and development as an enabler of competitive priorities and subsequently as an influencer of manufacturing performance. This study has found that, surprisingly, only one of three competitive factors (product innovation) impacts directly on organizational decisions to manage and develop employees. The other two competitive priorities (customer focus and delivery) show no relationship with employee management and development. This study has also shown that employee management has a positive relationship with three dimensions of manufacturing performance-quality performance, production flexibility and operations cost. In addition, the study also established that employee management and development mediate between product innovation and manufacturing performance. Finally, the importance of focusing on innovation-led practices that relate to positive environmental attributes have also been suggested as an outcome of this study.

Finally, the study limitations are presented. This study is predominantly based on manufacturers operating in developing Asian countries and does not include countries like Japan where employee involvement has been entrenched for decades. Future research may validate the studied model in manufacturing organizations operating in different countries.

Author Contributions: Conceptualization, D.A. and P.-L.T.; methodology, P.-L.T.; formal analysis, P.-L.T.; writing-original draft preparation, D.A.; writing—review and editing, D.A., P.-L.T., P.K.A., E.A. and P.R. All authors have read and agreed to the published version of the manuscript.

Funding: This research received no external funding.

Acknowledgments: We gratefully acknowledge the support of our research participants and the project partners of the sixth edition of the International Manufacturing Strategy Survey (IMSS), without which the present study could not have been completed. This research was supported by Bualuang ASEAN Chair Professorship Scheme and Thammasat Business School.

Conflicts of Interest: The authors declare no conflict of interest.

\section{References}

1. Zhang, C.; Wang, Z.; Ding, K.; Chan, F.T.S.; Ji, W. An Energy-Aware Cyber Physical System for Energy Big Data Analysis and Recessive Production Anomalies Detection in Discrete Manufacturing Workshops. Int. J. Prod. Res. 2020, 1-19. [CrossRef]

2. Abubakr, M.; Abbas, A.T.; Tomaz, I.; Soliman, M.S.; Luqman, M.; Hegab, H. Sustainable and Smart Manufacturing: An Integrated Approach. Sustainability 2020, 12, 2280. [CrossRef] 
3. Qureshi, M.I.; Rasiah, R.; Al-Ghazali, B.M.; Haider, M.; Jambari, H.; Iswan; Sasmoko. Modeling Work Practices under Socio-Technical Systems for Sustainable Manufacturing Performance. Sustainability 2019, 11, 4294. [CrossRef]

4. Dubey, R.; Gunasekaran, A.; Ali, S.S. Exploring the Relationship between Leadership, Operational Practices, Institutional Pressures and Environmental Performance: A Framework for Green Supply Chain. Int. J. Prod. Econ. 2015, 160, 120-132. [CrossRef]

5. Zhu, Q.; Geng, Y.; Lai, K.H. Circular Economy Practices among Chinese Manufacturers Varying in EnvironmentalOriented Supply Chain Cooperation and the Performance Implications. J. Environ. Manag. 2010, 91, 1324-1331. [CrossRef]

6. Zailani, S.; Jeyaraman, K.; Vengadasan, G.; Premkumar, R. Sustainable Supply Chain Management (SSCM) in Malaysia: A survey. Int. J. Prod. Econ. 2012, 140, 330-340. [CrossRef]

7. Wu, S.J. Assessing the Individual and Synergistic Effects of Quality Management Practices on Operations Performance. Int. J. Prod. Perform. Manag. 2020, 69, 297-320. [CrossRef]

8. Zhao, X.; Sum, C.C.; Qi, Y.; Zhang, H.; Lee, T.S. A Taxonomy of Manufacturing Strategies in China. J. Oper. Manag. 2006, 24, 621-636. [CrossRef]

9. Ward, P.T.; Duray, R.; Leong, G.K.; Sum, C.C. Business Environment, Operations Strategy, and Performance: An Empirical Study of Singapore Manufacturers. J. Oper. Manag. 1995, 13, 99-115. [CrossRef]

10. Miller, J.G.; Roth, A.V. A Taxonomy of Manufacturing Strategies. Manag. Sci. 1994, 40, 285-304. [CrossRef]

11. Berry, W.L.; Klompmaker, J.E.; Bozarth, C.C.; Hill, T.J. Factory Focus: Segmenting Markets from an Operations Perspective. J. Oper. Manag. 1991, 10, 363-387. [CrossRef]

12. Prester, J. Competitive Priorities, Capabilities and Practices of Best Performers: Evidence from GMRG 4 Data. Total Qual. Manag. Bus. Excel. 2013, 24, 138-157. [CrossRef]

13. Cai, S.; Yang, Z. On the Relationship between Business Environment and Competitive Priorities: The Role of Performance Frontiers. Int. J. Prod. Econ. 2014, 151, 131-145. [CrossRef]

14. Kathuria, R.; Partovi, F.Y. Work Force Management Practices for Manufacturing Flexibility. J. Oper. Manag. 1999, 18, 21-39. [CrossRef]

15. Lam, M.; O’Donnell, M.; Robertson, D. Achieving Employee Commitment for Continuous Improvement Initiatives. Int. J. Oper. Prod. Manag. 2015, 35, 201-215. [CrossRef]

16. Lee, F.-H.; Lee, T.-Z.; Wu, W.-Y. The Relationship between Human Resource Management Practices, Business Strategy and Firm Performance: Evidence from Steel Industry in Taiwan. Int. J. Hum. Resour. Manag. 2010, 21, 1351-1372. [CrossRef]

17. Mann, R.; Adebanjo, D.; Tickle, M. Deployment of Business Excellence in Asia: An Exploratory Study. Int. J. Qual. Reliab. Manag. 2011, 28, 604-627. [CrossRef]

18. Laosirihongthong, T.; Teh, P.L.; Adebanjo, D. Revisiting Quality Management and Performance. Ind. Manag. Data Syst. 2013, 113, 990-1006. [CrossRef]

19. Jagoda, K.; Kiridena, S. Operations Strategy Processes and Performance: Insights from the Contract Apparel Manufacturing Industry. J. Manuf. Technol. Manag. 2015, 26, 261-279. [CrossRef]

20. Jayaram, J.; Droge, C.; Vickery, S.K. The Impact of Human Resource Management Practices on Manufacturing Performance. J. Oper. Manag. 1999, 18, 1-20. [CrossRef]

21. Hayes, R.H.; Wheelwright, S.C. Restoring Our Competitive Edge: Competing through Manufacturing; John Wiley: New York, NY, USA, 1984.

22. Phusavat, K.; Kanchana, R. Competitive Priorities for Service Providers: Perspectives from Thailand. Ind. Manag. Data Syst. 2008, 108, 5-21. [CrossRef]

23. Prajogo, D. The Implementation of Operations Management Techniques in Service Organizations: An Australian Perspective. Int. J. Oper. Prod. Manag. 2006, 26, 1374-1390. [CrossRef]

24. Thürer, M.; Godinho Filho, M.; Stevenson, M.; Fredendall, L.D. Competitive Priorities of Small Manufacturers in Brazil. Ind. Manag. Data Syst. 2013, 113, 856-874. [CrossRef]

25. Foo, G.; Friedman, D.J. Variability and Capability: The Foundation of Competitive Operations Performance. AT T Technol. J. 1992, 71, 2-9. [CrossRef]

26. Kathuria, R.; Porth, S.J.; Kathuria, N.N.; Kohli, T.K. Competitive Priorities and Strategic Consensus in Emerging Economies: Evidence from India. Int. J. Oper. Prod. Manag. 2010, 30, 879-896. [CrossRef]

27. Ward, P.T.; McCreery, J.K.; Ritzman, L.P.; Sharma, D. Competitive Priorities in Operations Management. Dec. Sci. 1998, 29, 1035-1046. [CrossRef] 
28. Leong, G.K.; Synder, D.L.; Ward, P.T. Research in the Process and Content of Manufacturing Strategy. OMEGA Int. J. Manag. Sci. 1990, 18, 109-122. [CrossRef]

29. Verma, R.; Young, S.T. Configurations of Low-Contact Services. J. Oper. Manag. 2000, 18, 643-661. [CrossRef]

30. Lee, V.H.; Ooi, K.B.; Chong, A.Y.L.; Sohal, A. The Effects of Supply Chain Management on Technological Innovation: The Mediating Role of Guanxi. Int. J. Prod. Econ. 2018, 205, 15-29. [CrossRef]

31. Chan, H.K.; Yee, R.W.Y.; Dai, J.; Lim, M.K. The Moderating Effect of Environmental Dynamism on Green Product Innovation and Performance. Int. J. Prod. Econ. 2016, 181, 384-391. [CrossRef]

32. Van Iwaarden, J.; van der Wiele, T. The Effects of Increasing Product Variety and Shortening Product Life Cycles on the Use of Quality Management Systems. Int. J. Qual. Reliab. Manag. 2012, 29, 470-500. [CrossRef]

33. Laosirihongthong, T.; Tan, K.-C.; Adebanjo, D. Supply Chain Management in ASEAN Automotive Manufacturing Industry. Int. J. Logis. Res. App. 2011, 14, 317-333. [CrossRef]

34. Ferdows, K.; De Meyer, A. Lasting Improvements in Manufacturing Performance: In Search of a New Theory. J. Oper. Manag. 1990, 9, 168-184. [CrossRef]

35. Sanz-Valle, R.; Sabater-Sanchez, R.; Aragon-Sanchez, A. Human Resource Management and Business Strategy Links: An Empirical Study. Int. J. Hum. Resour. Manag. 1999, 10, 655-671. [CrossRef]

36. Schuler, R.S.; Jackson, S.E. Linking Competitive Strategies with Human Resource Management Practices. Acad. Manag. Perspect. 1987, 1, 207-219. [CrossRef]

37. Miles, R.E.; Snow, C.C. Designing Strategic Human Resources Systems; Institute of Industrial Relations, University of California: Oakland, CA, USA, 1984; pp. 36-52.

38. Raghuram, S. Linking Staffing and Training Practices with Business Strategy: A Theoretical Perspective. Hum. Resour. Dev. Quar. 1994, 5, 237-251. [CrossRef]

39. Medlin, B.; Green, K.W.; Wright, A.D. Comprehensive Management Practices and Policies Performance Model. Ind. Manag. Data Syst. 2016, 116, 1043-1060. [CrossRef]

40. Indradevi, R. Training for Most Capable Workforce. Adv. Manag. 2010, 3, $49-54$.

41. Otoo, F.N.K.; Otoo, E.A.; Abledu, G.K.; Bhardwaj, A. Impact of Human Resource Development (HRD) Practices on Pharmaceutical Industry's Performance: The Mediating Role of Employee Performance. Eur. J. Train. Dev. 2019, 43, 188-210. [CrossRef]

42. Kumar, R.; Singh, H. Exploring the Success Factors for Examining the Potential of Manufacturing System Output. Benchmarking Int. J. 2018, 25, 1171-1193. [CrossRef]

43. Bandyopadhyay, C.; Srivastava, K. HR Signals in the Context of HRM-firm Performance Relationship: Development of a Conceptual Framework. Int. J. Prod. Perf. Manag. 2020. [CrossRef]

44. Potnuru, R.K.G.; Sahoo, C.K. HRD Interventions, Employee Competencies and Organizational Effectiveness: An Empirical Study. Eur. J. Train. Dev. 2016, 40, 345-365. [CrossRef]

45. Yu, W.; Ramanathan, R.; Wang, X.; Yang, J. Operations Capability, Productivity and Business Performance: The Moderating Effect of Environmental Dynamism. Ind. Manag. Data Syst. 2018, 118, 126-143. [CrossRef]

46. Halley, A.; Beaulieu, M. Mastery of Operational Competencies in the Context of Supply Chain Management. Supply Chain Manag. Int. J. 2009, 14, 49-63. [CrossRef]

47. Barney, J.; Griffin, R. The Management of Organization: Strategy, Structure, Behavior; Houghton Mifflin Co.: Boston, MA, USA, 1992.

48. Amabile, T.M.; Conti, R.; Coon, H.; Lazenby, J.; Herron, M. Assessing the Work Environment for Creativity. Acad. Manag. J. 1996, 39, 1154-1184. [CrossRef]

49. Steen, A.; Welch, D.; McCormack, D. Conflicting Conceptualizations of Human Resource Accounting. J. Hum. Resour. Costing Account. 2011, 15, 299-312. [CrossRef]

50. Gannon, J.M.; Doherty, L.; Roper, A. The Role of Strategic Groups in Understanding Strategic Human Resource Management. Pers. Rev. 2012, 41, 513-546. [CrossRef]

51. Woodall, J.; Scott-Jackson, W.; Newham, T.; Gurney, M. Making the Decision to Outsource Human Resources. Pers. Rev. 2009, 38, 236-252. [CrossRef]

52. Peteraf, M.A. The Cornerstones of Competitive Advantage: A Resource-Based View. Strategic Manag. J. 1993, 14, 179-191. [CrossRef]

53. Drohomeretski, E.; Gouvea da Costa, S.E.; Pinheiro de Lima, E.; Garbuio, P.A.D.R. Lean, Six Sigma and Lean Six Sigma: An Analysis based on Operations Strategy. Int. J. Prod. Res. 2014, 52, 804-824. [CrossRef]

54. Boyer, K.K.; McDermott, C. Strategic Consensus in Operations Strategy. J. Oper. Manag. 1999, 17, $289-305$. [CrossRef] 
55. Liu, Y.; Liang, L. Evaluating and Developing Resource-Based Operations Strategy for Competitive Advantage: An Exploratory Study of Finnish High-Tech Manufacturing Industries. Int. J. Prod. Res. 2015, 53, 1019-1037. [CrossRef]

56. Carranza, J.E. Product Innovation and Adoption in Market Equilibrium: The Case of Digital Camera. Int. J. Ind. Organ. 2010, 28, 604-618. [CrossRef]

57. Verhees, F.J.H.M.; Meulenberg, M.T.G. Market Orientation, Innovativeness, Product Innovation, and Performance in Small Firms. J. Small Bus. Manag. 2004, 42, 134-154. [CrossRef]

58. Thompson, A.A.; Strickland, A.J.; Gamble, J.E. Crafting and Executing Strategy: The Quest for Competitive Advantage: Concepts and Cases, 14th ed.; McGraw-Hill Education: Boston, MA, USA, 2005.

59. Laosirihongthong, T.; Prajogo, D.; Adebanjo, D. The Relationships between Firm's Strategy, Resources, and Innovation Performance: Resources-Based View Perspective. Prod. Plan. Control Manag. Oper. 2014, 25, 1231-1246. [CrossRef]

60. Subramaniam, M.; Youndt, M.A. The Influence of Intellectual Capital on the Types of Innovative Capabilities. Acad. Manag. J. 2005, 48, 450-463. [CrossRef]

61. Gumusluoğlu, L.; Ilsev, A. Transformational Leadership and Organizational Innovation: The Roles of Internal and External Support for Innovation. J. Prod. Innov. Manag. 2009, 26, 264-277. [CrossRef]

62. Ren, S.; Eisingerich, A.B.; Tsai, H.-T. Search Scope and Innovation Performance of Emerging-Market Firms. J. Bus. Res. 2015, 68, 102-108. [CrossRef]

63. Søndergaard, E.; Oehmen, J.; Ahmed-Kristensen, S. Extension of Internationalisation Models: Drivers and Processes for the Globalisation of Product Development-A Comparison of Danish and Chinese Engineering Firms. Prod. Plan. Control: Manag. Oper. 2016, 27, 1112-1123. [CrossRef]

64. Famiyeh, S.; Kwarteng, A.; Asante-Darko, D.; Dadzie, S.A. Green Supply Chain Management Initiatives and Operational Competitive Performance. Benchmarking Int. J. 2018, 25, 607-631. [CrossRef]

65. Guillon, O.; Cezanne, C. Employee Loyalty and Organizational Performance: A Critical Survey. J. Organ. Chang. Manag. 2014, 27, 839-850. [CrossRef]

66. Almatrooshi, B.; Singh, S.K.; Farouk, S. Determinants of Organizational Performance: A Proposed Framework. Int. J. Prod. Perform. Manag. 2016, 65, 844-859. [CrossRef]

67. Sarfaraz, A.; Jenab, K.; Bowker, A. A View of Development in Management for Increasing Profitability in the Corporate Landscape. Benchmarking Int. J. 2015, 22, 120-134. [CrossRef]

68. Melián-González, S.; Bulchand-Gidumal, J.; González López-Valcárcel, B. New Evidence of the Relationship between Employee Satisfaction and Firm Economic Performance. Pers. Rev. 2015, 44, 906-929. [CrossRef]

69. Oakland, S.; Oakland, J.S. Current People Management Activities in World-Class Organizations. Total Qual. Manag. 2001, 12, 773-788. [CrossRef]

70. Nasim, K. Role of Internal and External Organizational Factors in TQM Implementation: A Systematic Literature Review and Theoretical Framework. Int. J. Qual. Reliab. Manag. 2018, 35, 1014-1033. [CrossRef]

71. Bourne, M.; Pavlov, A.; Franco-Santos, M.; Lucianetti, L.; Mura, M. Generating Organizational Performance: The Contributing Effects of Performance Measurement and Human Resource Management Practices. Int. J. Oper. Prod. Manag. 2013, 33, 1599-1622. [CrossRef]

72. Hanna, M.D.; Newman, W.R.; Johnson, P. Linking Operational and Environmental Improvement through Employee Involvement. Int. J. Oper. Prod. Manag. 2000, 20, 148-165. [CrossRef]

73. Thanyawatpornkul, R.; Siengthai, S.; Johri, L.M. Employee's Perspective towards Strategy Execution in Facility Management in Thailand. Facilities 2016, 34, 682-702. [CrossRef]

74. Walker, H.; Sisto, L.D.; McBain, D. Drivers and Barriers to Environmental Supply Chain Management Practices: Lessons from the Public and Private Sectors. J. Purchas. Sup. Manag. 2008, 14, 69-85. [CrossRef]

75. Ahmad, S.; Schroeder, R.G. The Impact of Human Resource Management Practices on Operational Performance: Recognizing Country and Industry Differences. J. Oper. Manag. 2003, 21, 19-43. [CrossRef]

76. Cagliano, R.; Acur, N.; Boer, H. Patterns of Change in Manufacturing Strategy Configurations. Int. J. Oper. Prod. Manag. 2005, 25, 701-718. [CrossRef]

77. Cagliano, R.; Caniato, F.; Golini, R.; Longoni, A.; Micelotta, E. The Impact of Country Culture on the Adoption of New Forms of Work Organization. Int. J. Oper. Prod. Manag. 2011, 31, 297-323. [CrossRef]

78. Sveiby, K.; Simons, R. Collaborative Climate and Effectiveness of Knowledge Work-An Empirical Study. J. Knowl. Manag. 2002, 6, 420-433. [CrossRef] 
79. Rogg, K.L.; Schmidt, D.B.; Shull, C.; Schmitt, N. Human Resource Practices, Organizational Climate, and Customer Satisfaction. J. Manag. 2001, 27, 431-449. [CrossRef]

80. Cagliano, R.; Caniato, F.; Longoni, A.; Spina, G. Alternative Uses of Temporary Work and New Forms of Work Organization. Prod. Plan. Control Manag. Oper. 2014, 25, 762-782. [CrossRef]

81. Sitkin, S.B.; Sutcliffe, K.M.; Schroeder, R.G. Distinguishing Control from Learning in Total Quality Management: A Contingency Perspective. Acad. Manag. Rev. 1994, 19, 537-564. [CrossRef]

82. Garvin, D. Competing on the Eight Dimensions of Quality. Harv. Bus. Rev. 1987, 65, 101-109.

83. Forza, C.; Filippini, R. TQM Impact on Quality Conformance and Customer Satisfaction: A Causal Model. Int. J. Prod. Econ. 1998, 55, 1-20. [CrossRef]

84. Ahmed, J.U. Modern Approaches to Product Reliability Improvement. Int. J. Qual. Reliab. Manag. 1996, 13, 27-41. [CrossRef]

85. Kimura, F.; Matoba, Y.; Mitsui, K. Designing Product Reliability Based on Total Product Lifecycle Modelling. CIRP Ann. Manuf. Technol. 2007, 56, 163-166. [CrossRef]

86. Jack, E.P.; Raturi, A. Sources of Volume Flexibility and Their Impact on Performance. J. Oper. Manag. 2002, 20, 519-548. [CrossRef]

87. Hallgren, M.; Olhager, J. Flexibility Configurations: Empirical Analysis of Volume and Product Mix Flexibility. OMEGA Int. J. Manag. Sci. 2009, 37, 746-756. [CrossRef]

88. Woo, Y.Y.; Hsu, S.L.; Wu, S. An Integrated Inventory Model for a Single Vendor and Multiple Buyers with Ordering Cost Reduction. Int. J. Prod. Econ. 2001, 73, 203-215. [CrossRef]

89. Rao, P. Greening the Supply Chain: A New Initiative in South East Asia. Int. J. Oper. Prod. Manag. 2002, 22, 632-655. [CrossRef]

90. The International Manufacturing Strategy Survey. Available online: http://www.manufacturingstrategy.net/ (accessed on 7 June 2020).

91. Hair, J.F.; Babin, B.J.; Anderson, R.E.; Black, W.C. Multivariate Data Analysis, 8th ed.; Cengage: Boston, MA, USA, 2018.

92. Bagozzi, R.P.; Yi, Y. On the Evaluation of Structural Equation Models. Acad. Mark. Sci. 1988, 16, 74-94. [CrossRef]

93. Fornell, C.; Larcker, D.F. Evaluating Structural Equation Models with Unobservable Variables and Measurement Error. J. Mark. Res. 1981, 18, 39-50. [CrossRef]

94. Preacher, K.J.; Hayes, A.F. SPSS and SAS Procedures for Estimating Indirect Effects in Simple Mediation Models. Behav. Res. Methods Instrum. Comput. 2004, 36, 717-731. [CrossRef] [PubMed]

95. Peng, D.X.; Schroeder, R.G.; Shah, R. Competitive Priorities, Plant Improvement and Innovation Capabilities, and Operational Performance: A Test of Two Forms of Fit. Int. J. Oper. Prod. Manag. 2011, 31, 484-510. [CrossRef]

96. Filho, A.G.A.; Nogueira, E.; Bento, P.E.G. Operations Strategies of Engine Assembly Plants in the Brazilian Automotive Industry. Int. J. Oper. Prod. Manag. 2015, 35, 817-838. [CrossRef]

97. Yen, H.R.; Sheu, C. Aligning ERP Implementation with Competitive Priorities of Manufacturing Firms: An Exploratory Study. Int. J. Prod. Econ. 2004, 92, 207-220. [CrossRef]

98. Chan, L.L.M.; Shaffer, M.A.; Snape, E. In Search of Sustained Competitive Advantage: The Impact of Organizational Culture, Competitive Strategy and Human Resource Management Practices on Firm Performance. Int. J. Hum. Resour. Manag. 2004, 15, 17-35. [CrossRef]

99. Alagaraja, M.; Cumberland, D.M.; Choi, N. The Mediating Role of Leadership and People Management Practices on HRD and Organizational Performance. Hum. Resour. Dev. Int. 2015, 18, 220-234. [CrossRef]

100. Zhu, Y.; Warner, M.; Rowley, C. Human Resource Management with 'Asian' Characteristics: A Hybrid People-Management System in East Asia. Int. J. Hum. Resour. Manag. 2007, 18, 745-768. [CrossRef]

101. Kumar, S.; Teichman, S.; Timpernagel, T. A Green Supply Chain is a Requirement for Profitability. Int. J. Prod. Res. 2012, 50, 1278-1296. [CrossRef]

102. Testa, F.; Iraldo, F. Shadows and Lights of GSCM (Green Supply Chain Management): Determinants and Effects of These Practices Based on a Multi-National Study. J. Clean. Prod. 2010, 18, 953-962. [CrossRef] 